\title{
Post-dam Channel and Floodplain Adjustment along the Lower Volga River, Russia
}

\author{
Hans Middelkoop, Andrei M. Alabyan, Dmitry B. Babich \\ and Vadim V. Ivanov
}

\begin{abstract}
The Volga River in the Russian Federation has been regulated by a cascade of reservoir dams since the 1950-1960s. This chapter presents an overview of the main hydrological and morphological responses of the Volga River downstream of the Volgograd reservoir dam. Regulation caused a decrease in magnitude of the spring peak flow, an earlier start and peak of the flood and a considerably steeper rise and fall of the flood. Morphological responses include a considerable channel incision in the river stretch downstream of the Volgograd dam. Furthermore, the reduction in peak flow magnitude results in a general tendency of silting up of secondary channels, and promotes vegetation colonisation along the active parts of the floodplain. Restoring the natural flow regime and morphodynamics will be problematic, particularly in view of the potential hydrological impacts of climate change.
\end{abstract}

Keywords Volga River - Regulation - Dams · Hydrological regime Channel morphology $\cdot$ Flood plain

\section{Introduction}

The Volga is among the largest rivers in Europe and, as many of these rivers, it has been heavily modified by humans (Tockner et al. 2009). The most dramatic impacts have been imposed by the construction of a cascade of 13 large dams and reservoirs constructed during the 1950-1960s. The most downstream reservoiris located near the city of Volgograd. Downstream of Volgograd the lower Volga retains the natural channel morphology, with active bank erosion and bar formation, while the river borders a large floodplain that is seasonally inundated. The construction of the reservoirs and subsequent regulation has considerably disturbed the natural discharge

\footnotetext{
H. Middelkoop ( $\bowtie)$

Department of Physical Geography, University of Utrecht, Utrecht, Netherlands

e-mail: h.middelkoop@uu.nl

A.M. Alabyan · D.B. Babich · V.V. Ivanov

Department of Geography, Moscow State University, Moscow, Russian Federation

(C) Springer New York 2015

P. F. Hudson, H. Middelkoop (eds.), Geomorphic Approaches to Integrated Floodplain

Management of Lowland Fluvial Systems in North America and Europe,

DOI 10.1007/978-1-4939-2380-9 10
} 
regime of the lower Volga. This in turn has affected sediment transport, channel morphodynamics, while also the annual flood pulse of the floodplain ecosystem has been impacted. When compared to many other European rivers (e.g. Tockner et al. 2008) the lower Volga is a unique example in the sense that its lower course has remained in a relatively natural state, allowing the 'natural' response to damming to be studied. Over the past years much data on these effects has been collected by scientists and government agencies, and is awaiting investigation and communication by researchers to a wider international audience.

In this study, we investigate the hydrological and morphological changes that occurred in the lower Volga River downstream of the Volgograd dam after the establishment of large main-stem reservoirs. We illustrate these changes for the entire lower Volga, and then focus on the Volgograd reach immediately downstream of the dam, and on the development of a point bar at about $100 \mathrm{~km}$ downstream of the dam. We conclude by providing a long-term perspective on the future development of the lower Volga river system.

The work presented in this study is a synthesis of long-term research conducted by Moscow State University (MSU), followed by joint projects with Utrecht University and the Netherlands Institute for Inland Water Management and Wastewater Treatment (RIZA - now Deltares) and the University of Volgograd over the past decade (Middelkoop 2005). The results are based on a combination of (1) field surveys on channel morphology and deformation and bar development using depth sounders, sonar-echo instruments, leveling-instruments and GPS (Ivanov et al. 2006; Korotaev et al. 2009), (2) Remote Sensing image analysis of channel and floodplain morphology, including US CORONA satellite of 1960s and early 1970s and LANDSAT TM, (3) analyses of time series of navigation maps (1914-2003) indicating channel depth, position of channel banks, bars, islands and shore vegetation and (4) observation records of river discharge, water levels and discontinuous records of sediment load available at MSU. The latter data source is increasingly becoming accessible through public web-portals (www.waterinfo.ru/33/Rivers/index.php).

\section{The Lower Volga}

The Volga River drains an area of 1.36 million $\mathrm{km}^{2}$ of the Eastern European Plain within the Russian Federation (Fig. 1a). The main river and most of its tributaries flow from the north to the south through several different geographical and vegetation zones, including taiga, hard- and softwood forests, steppes, semi-arid and arid zones. The major tributaries are the Oka, the Belaya, the Vyatka and the Kama Rivers, each of which is longer than $1000 \mathrm{~km}$ and have catchments exceeding $100,000 \mathrm{~km}^{2}$. The total annual discharge of the lower Volga at Volgograd is about $260 \mathrm{~km}^{3}$. Downstream of Volgograd there are no tributaries to the Volga and instead the Akhtuba, a minor distributary branch, separates from the lower Volga (Fig. 1b). Both distributaries enclose a $20-30 \mathrm{~km}$ wide $\mathrm{x} \sim 400 \mathrm{~km}$ long natural floodplain that is embedded in a 30-40 m deep valley, incised in Pleistocene marine sandy and 

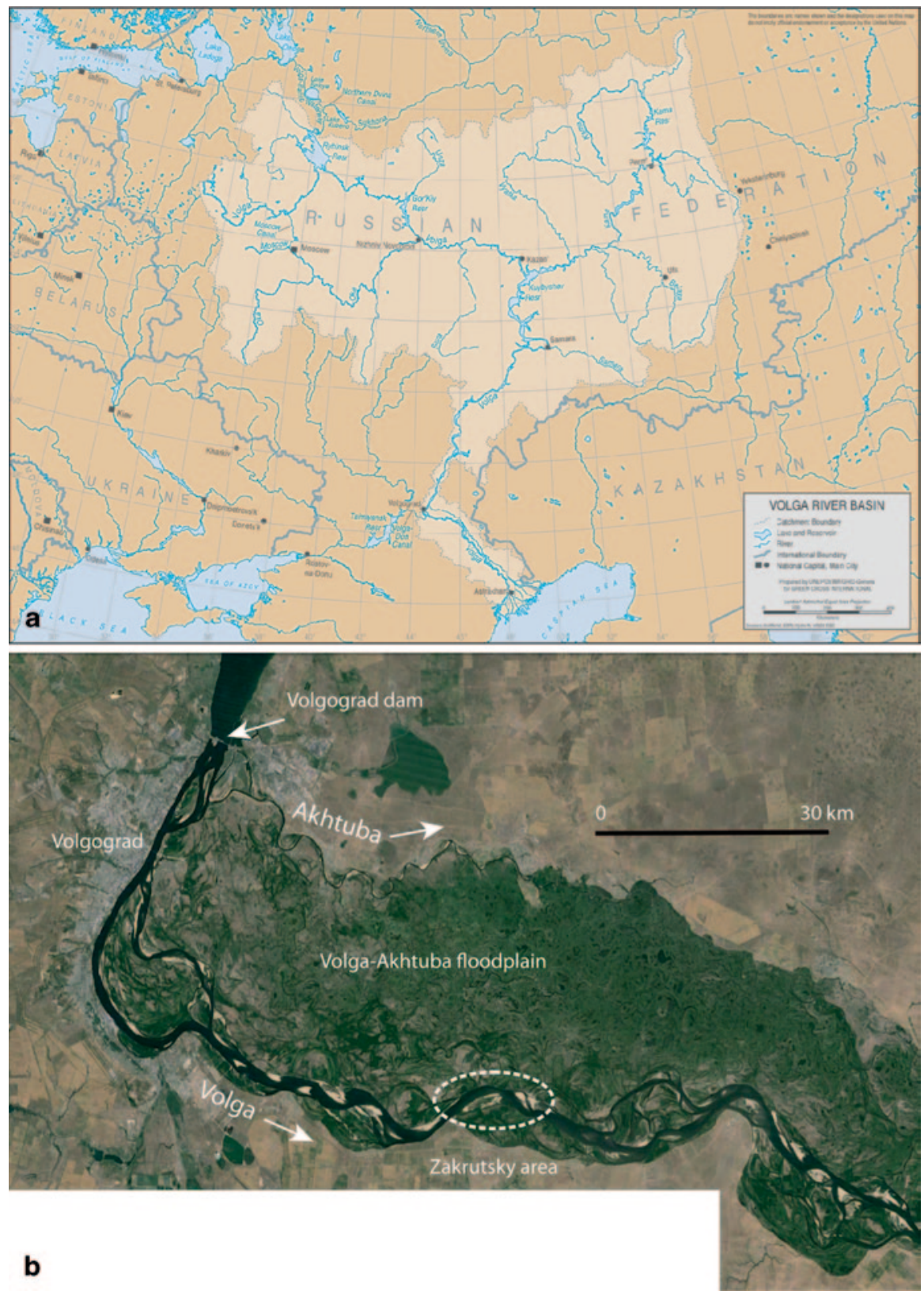

Fig. 1 a The Volga river basin (source: UNEP/DEWA/Grid-Geneva), b The lower Volga and western part of the Volga-Akhtuba floodplain 
clay deposits of the former Caspian Sea (Goretski 1966; Korotaev et al. 2009). The Volga debouches in the Caspian Sea at about $28 \mathrm{~m}$ below global mean sea level. The Volga-Akhtuba floodplain is dissected by numerous small channels and thousands of lakes occur scattered within the floodplain. Only the sections that border the present main channels are active. The central portions comprise Early to Late Holocene complexes of inactive channels and pointbar ridges, with neither lateral erosion or overbank deposition.

The main course of the lower Volga is a typical lowland river, with an average gradient of about $6 \times 10^{-5}$ (Fig. 2). Channel width varies between $\sim 800 \mathrm{~m}$ and $2 \mathrm{~km}$. Maximum cross-channel depths during summer flow conditions vary along the river course between about $5 \mathrm{~m}$ in riffle zones and over $30 \mathrm{~m}$ in the deepest pools at the outside of bends. The grain size of the channel bed sediment of the Volga River is remarkably fine: downstream the Volgograd dam the bed sediment is currently dominated by sands with average median grain sizes between 0.15 and $0.50 \mathrm{~mm}$. This is because of the fine-grained character of the marine deposits in which the river is embedded. Further downstream, local occurrences of increased grain size of the channel bed sediment occur, mainly due to the contribution of sediment from bank erosion of valley sides and some bedrock exposures. At some sections the channel bottom is formed by exposed marine clays, and almost devoid of coarse bed load. Under average flow conditions $\left(\mathrm{Q} \sim 8000 \mathrm{~m}^{3} \mathrm{~s}^{-1}\right)$ specific stream power of the lower Volga is in about $3 \mathrm{Wm}^{-2}$, and Shields parameter $\sim 0.6$.

Annual discharge of the Volga River is about $259 \mathrm{~km}^{3} \mathrm{yr}^{-1}$ at the Volgograd dam, and about $253 \mathrm{~km}^{3} \mathrm{yr}^{-1}$ at the delta apex. The discharge regime of the Volga is characterized by a clear snowmelt peak in spring and a low-flow period in late summer-winter (Fig. 3). Peak flow occurs by the end of April to early May, and on average reaches up to $26,000 \mathrm{~m}^{3} \mathrm{~s}^{-1}$. In this period the Volga discharges about one third of its total annual discharge volume. During peak flow, the large floodplain between both branches inundates to a large extent for a period of several weeks (Górski et al. 2011).

The Volga River has major economic functions for the Russian Federation. It forms an essential component of Russia's transportation network of rivers and canals, linking the North (White Sea, Baltic Sea) to the South (Black Sea, Caspian Sea). The river is navigable over a distance of about $3200 \mathrm{~km}$, and it carries about two-thirds of all navigation traffic of the country. In the $1950 \mathrm{~s}$, a cascade of reservoirs was established in the Volga basin (Fig. 1a), of which the largest are the Gor'kovskoe (1955-1957), Kuibeshevskoe (1955-1957), Kamskoe (1954-1956), and Volgogradskoe (1958-1960), the latter being the last and most downstream reservoir. There are eight hydroelectric stations on the Volga River and three on the Kama River that together have a power production capacity of about 40 billion $\mathrm{kWh}$ (Demin 2005). This requires about $50 \mathrm{~km}^{3}$ water storage. Reservoir regulation provides sufficient navigation depth in the lower Volga during low-flow periods (i.e. $>4000 \mathrm{~m}^{3} \mathrm{~s}^{-1}$ which requires an annual volume of $47.3 \mathrm{~km}^{3}$ ). The reservoirs also have an important role in the provision of freshwater for irrigation, industry and domestic use. Water from the Volga is currently used to irrigate about 200 million ha of agriculture. Before $19553-6 \mathrm{~km}^{3}$ was annually diverted (1-2\% of total water runoff). To date, this is $24 \mathrm{~km}^{3}$ per year, which is $10 \%$ of the natural water runoff reaching the Volga delta. 


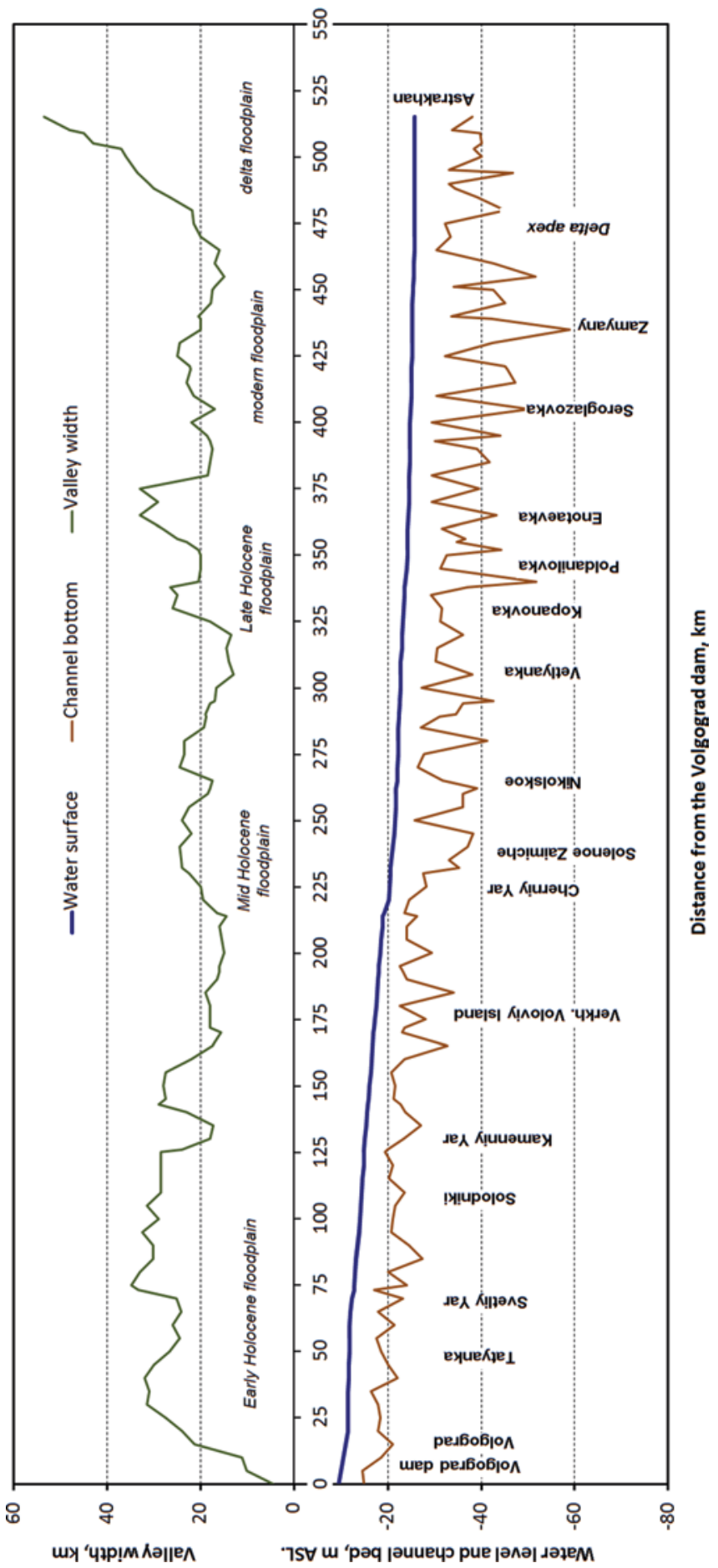

Fig. 2 Water level, channel bottom and valley width of the Lower Volga. (Modified from Korotaev et al. 2009) 


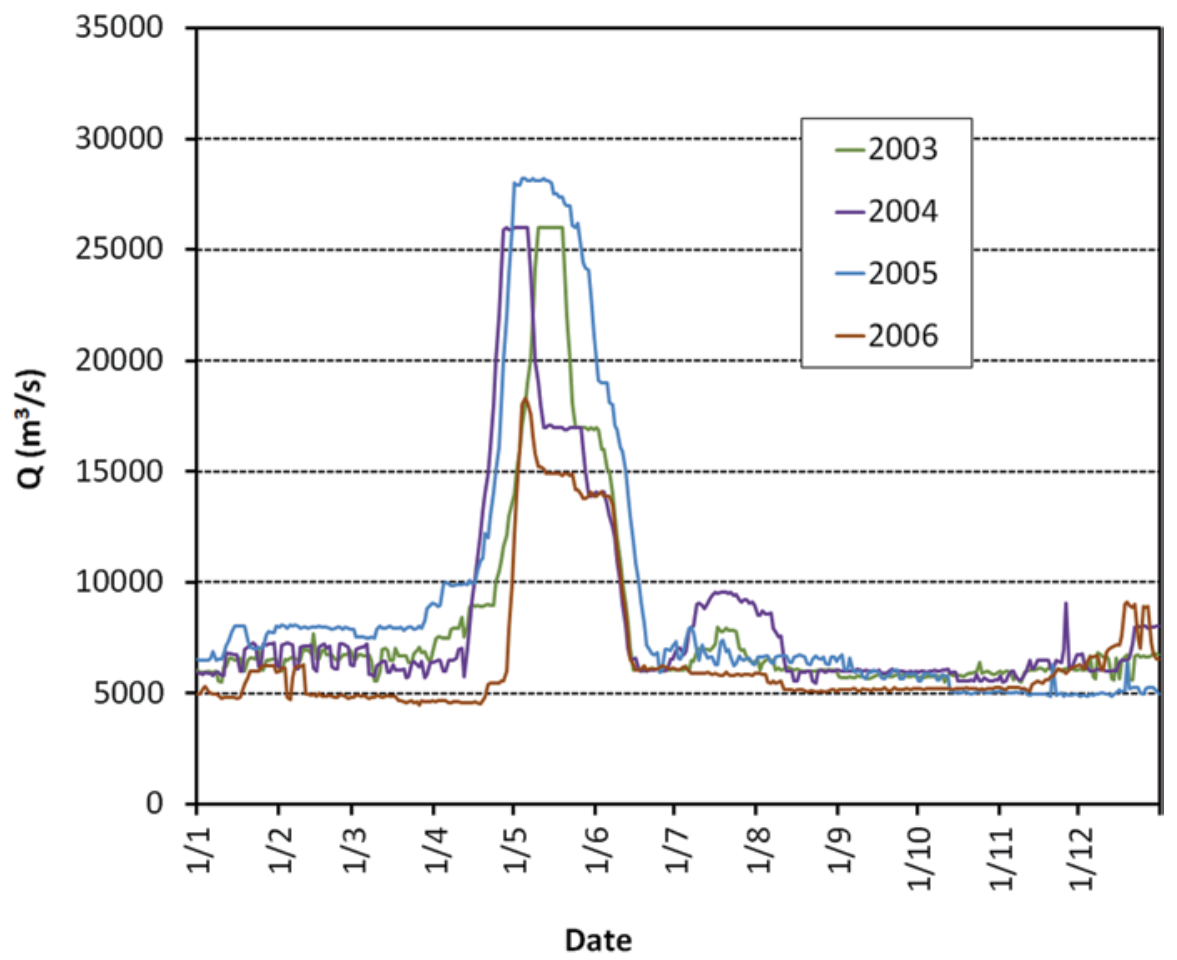

Fig. 3 Annual hydrograph of the Lower Volga at Volgograd for recent years. The figure shows the variation in regulated peak flows

\section{Impacts of the Reservoirs and Dams}

\subsection{Hydrology}

Before the construction of the reservoirs, the spring flood period started early May and reached its peak discharge in the first decade of June. The flood lasted on average for about 74 days. During this period, the lower Volga discharged about 32 $35 \%$ of its total annual discharge. The contribution of winter flow was generally less than $13 \%$ of the total annual Volga River discharge. Figure 4 shows these typical discharge characteristics of the Volga at Volgograd for the year 1936.

Although the present-day regime still demonstrates a spring peak flow, several characteristic changes occurred (Fig. 5). Firstly, the average discharge downstream of the reservoir decreased from 8380 to $7240 \mathrm{~m}^{3} \mathrm{~s}^{-1}$. Further, the duration of the peak flow decreased from about 74 to about 51 days. Most significant was the reduction in maximum discharge. While the unregulated mean peak discharge was about $34,500 \mathrm{~m}^{3} \mathrm{~s}^{-1}$, with the extreme of $51,900 \mathrm{~m}^{3} \mathrm{~s}^{-1}$ in 1926 , the average regulated peak discharge in the 1959-1999 period is about $26,800 \mathrm{~m}^{3} \mathrm{~s}^{-1}$. The highest post-dam peak flow was 34,100 in 1979 (Korotaev et al. 2004). The regulated spring flood 


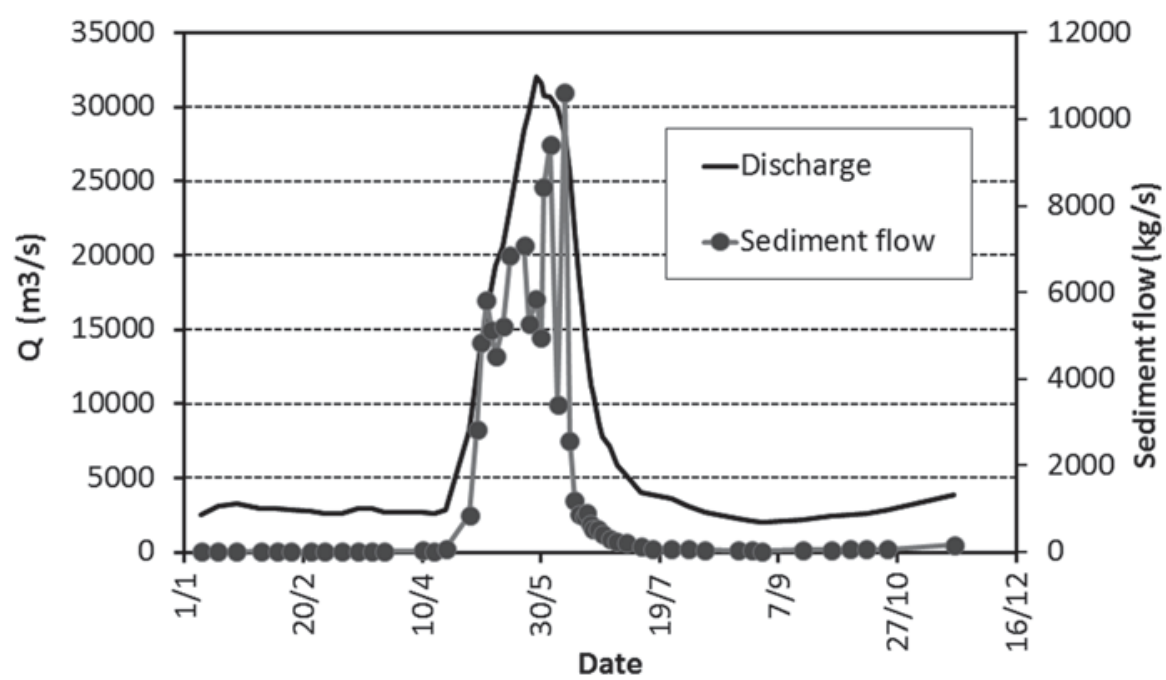

Fig. 4 Discharge and sediment load of the Volga in a pre-dam year (1936)

Monthly average discharge Volga at Volgograd, 1880-1980

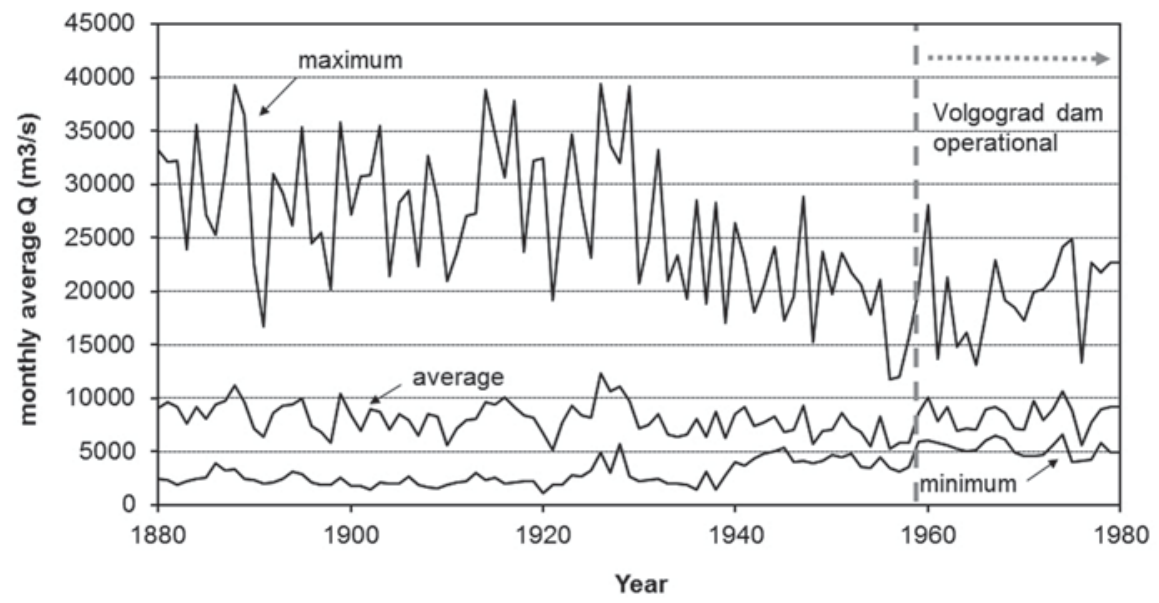

Fig. 5 Average, maximum and minimum monthly discharges of the Volga before and after construction of the reservoir dam

period starts and peaks a few weeks earlier and shows a considerably steeper rise and fall of the flood. The regulated discharge peak is followed by a period in which a relatively constant but increased discharge is maintained before the recession to low flow is achieved. Discharge during low flow periods has increased by almost $50 \%$ because of regulation, and contributes an average of $26 \%$ of the annual discharge. At a finer temporal resolution, the Volga discharge varies daily and weekly because of differences in electricity demand. 
The Akhtuba branch carries a small proportion of the total Volga discharge. Predam (until 1955) average annual water discharge Akhtuba's was $211 \mathrm{~m}^{3} \mathrm{~s}^{-1}$. The reduced peak flows under the regulated regime, in combination with a new artificial entrance of the Akhtuba constructed a few km downstream from the dam, resulted in a dramatic decrease of discharge into the Akhtuba. The average annual discharge reduced by almost $50 \%$ to about $100 \mathrm{~m}^{3} \mathrm{~s}^{-1}$, while the channel be completely dry during the summer-autumn low flow period, as it did in 1973. Subsequent siltationof the Akhtuba entrance has further reduced discharge into the Akhtuba. At present, maximum discharges through the Akhtuba are in the order of $2000-2500 \mathrm{~m}^{3} \mathrm{~s}^{-1}$, which is about $10 \%$ of the total Volga discharge. During peak flow, only $1-2 \%$ of the total amount of water discharged by the Volga enters the floodplain.

\subsection{Sediment Regime}

The largest contribution to the wash load in the Volga is from soil erosion in the central portions of the drainage basin, with estimated soil erosion rates between $<1$ and $>20 \mathrm{t} \mathrm{ha}^{-1} \mathrm{yr}^{-1}$ (UNESCO/IRTCES 2011). A few tens of $\mathrm{km}$ upstream of Volgograd the average annual sediment loads were $12-18.5 \mathrm{Mt} \mathrm{yr}^{-1}$ during the period from 1934 to 1953 (Baidin et al. 1956). At higher discharge years the vast majority of suspended sediment is mainly transported during the high flow period, such as in 1936 when nearly $95 \%$ of the total sediment load of $25.2 \mathrm{Mt}$ was discharged during the spring peak flow (Fig. 4). The estimated annual suspended sediment load discharged through the delta to the Caspian Sea during the pre-dam conditions is

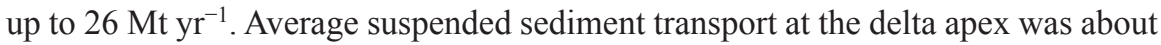
$400 \mathrm{~kg} \mathrm{~s}^{-1}$, with maxima up to $3870 \mathrm{~kg} \mathrm{~s}^{-1}$.

The reservoirs form major traps of sediment transported to the lower Volga, and all bed load is presently trapped by the reservoirs. After the reservoirs became operational the wash load initially decreased to $11.5 \mathrm{Mt} \mathrm{yr}^{-1}$, and then further decreased in subsequent years to 7.4 Mt per year. The period of lowest average wash load of 4.5 $\mathrm{Mt} \mathrm{yr}^{-1}$ occurred during from 1961 to 1977 , and was associated with relatively low peak flows. At the delta apex the annual suspended sediment reduced by $50 \%$ after damming, to an average of $7.9 \mathrm{Mt} \mathrm{yr}^{-1}$ from 1961 to $2006\left(211 \mathrm{~kg} \mathrm{~s}^{-1}\right)$. Annual maximum transport rates decreased to $2100 \mathrm{~kg} \mathrm{~s}^{-1}$, while maximum average suspended sediment concentration decreased from 56 to $34 \mathrm{~g} \mathrm{~m}^{-3}$. Both the reservoir trapping and the reduced water discharge resulted in the wash load of the Akhtuba branch to decrease to about $0.13 \mathrm{Mt} \mathrm{yr}^{-1}$, with an annual average suspended sediment concentration of $30 \mathrm{mg}^{-1}$.

It is evident that the dams and reservoirs have dramatically reduced sediment transport to the lower Volga valley and delta. To date, sediment released by channel incision and lateral bank erosion within the lower Volga reach downstream of the Volgograd dam forms a substantial source of Volga sediment, which is available to be further transported to the delta. A net increase in annual suspended sediment load of 7.3 Mt is found between Volgograd and the apex of the delta. 


\subsection{Channel Morphology}

\subsubsection{Larger-Scale Channel Dynamics}

Based on the channel planform shown on the 1914-2001 navigation maps and satellite imagery and field surveys, the lower Volga can be subdivided into three main reaches characterized by distinct changes in morphodynamics and channel geometry (Fig. 6). These reaches display varying response to dam construction: (1) Sect. 1 to the first section of 3, km 0- 100 (Fig. 5); (2) Sects. 3-8 from km 100 to 340, and (3) Sects. 8-11 from $\mathrm{km} 340$ to the delta apex at $\mathrm{km} \mathrm{357.} \mathrm{The} \mathrm{varying} \mathrm{response}$ of the river can be appreciated by considering the adjustment of eleven sections, including annual erosion and accretion rates per $\mathrm{km}$ of river (Fig. 7), and channel bars (Fig. 8) during the pre-dam period (1914-1944) and the post-dam period (1965-1982) and thereafter until 2000.

The pre-dam Volga channel reaches downstream from Volgograd had a $1.5-2 \mathrm{~km}$ wide, low-sinuosity, single thread channel that displayed only minor channel deformation. Average pre-dam lateral erosion rates were 5-8 m per year, which is less than 0.005 times the channel width. In the 1914-1944 period, floodplain erosion rates were in the order of $3-7 \times 10^{3} \mathrm{~m}^{2} \mathrm{~km}^{-1}$ per year, with lateral accretion rates being slightly less. Channel bar accretion rates were about $12 \times 10^{3} \mathrm{~m}^{2} \mathrm{~km}^{-1}$ per

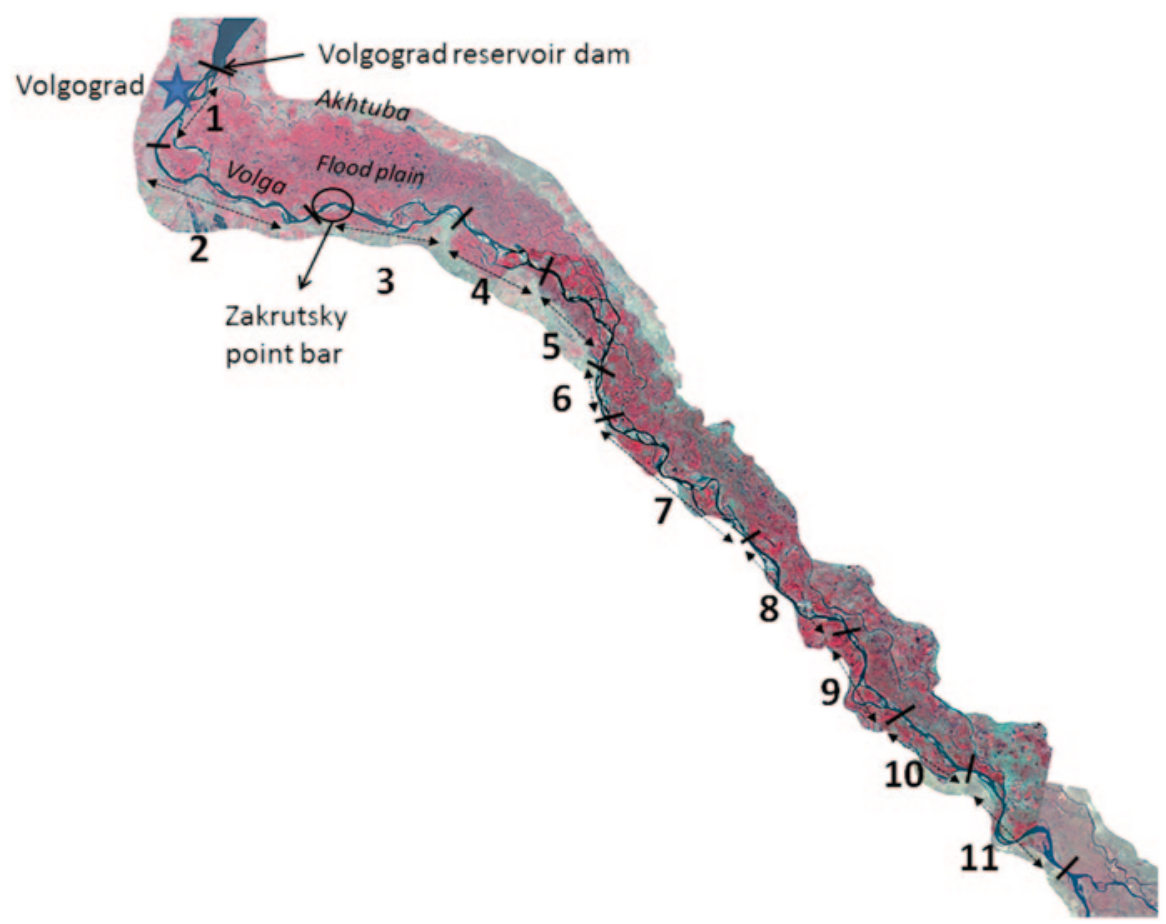

Fig. 6 River sections of the Lower Volga between the Volgograd reservoir dam and the delta apex 

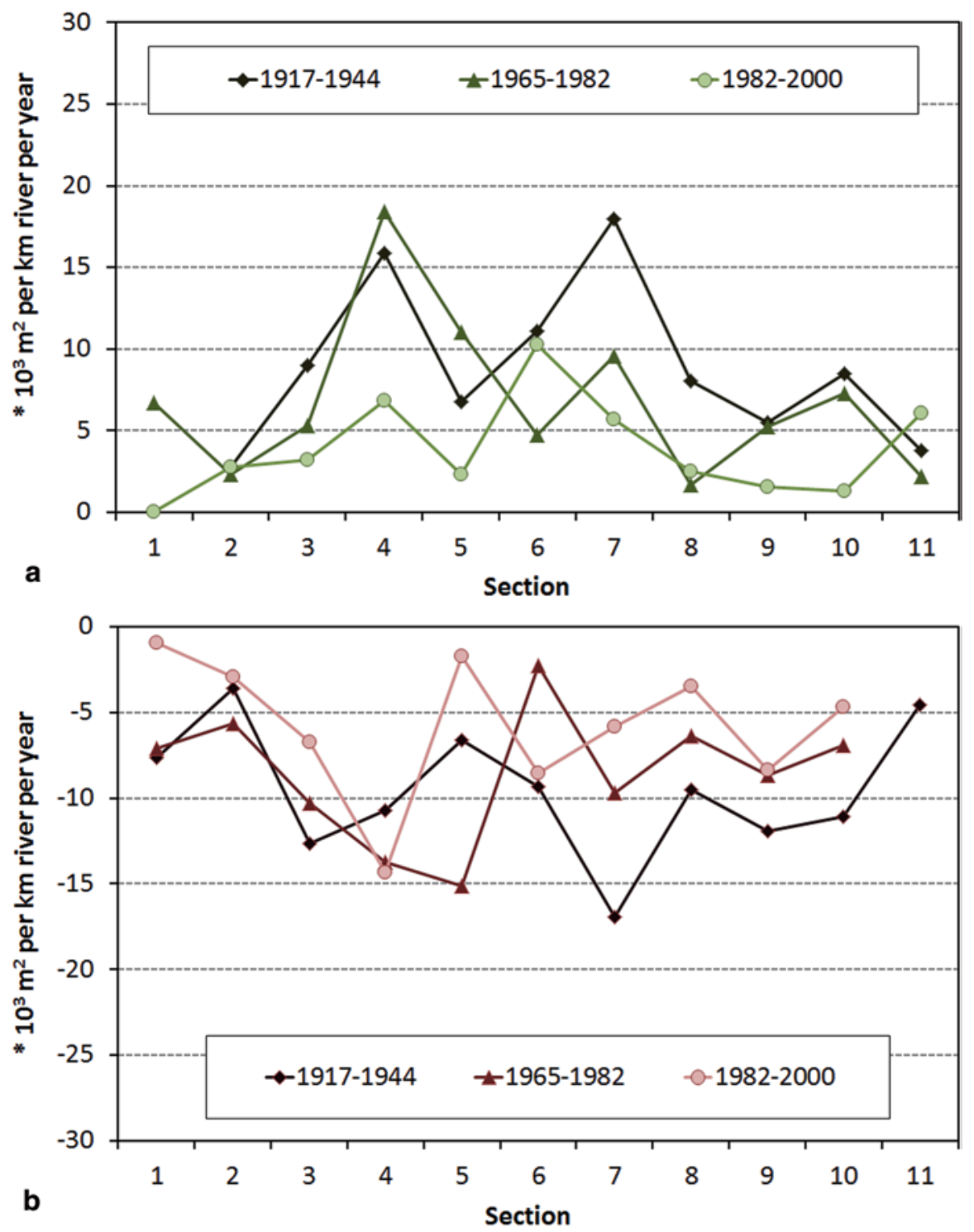

Fig. 7 a Bank erosion, b Lateral accretion rates along different sections of the Lower Volga before and after dam construction. Values are averages per km per year

year, while erosion rates were less than half this rate. In the first two decades after dam construction, rates of lateral bank erosion and accretion changed little, and in the most recent decades considerably decreased. Many channel bars were initially eroded after dam construction and in recent decades bar erosion has increased, while new bar formation rates are lower than in preceding decades. Erosion and accretion during the period 1986-2000 in the first $150 \mathrm{~km}$ clearly demonstrate a 

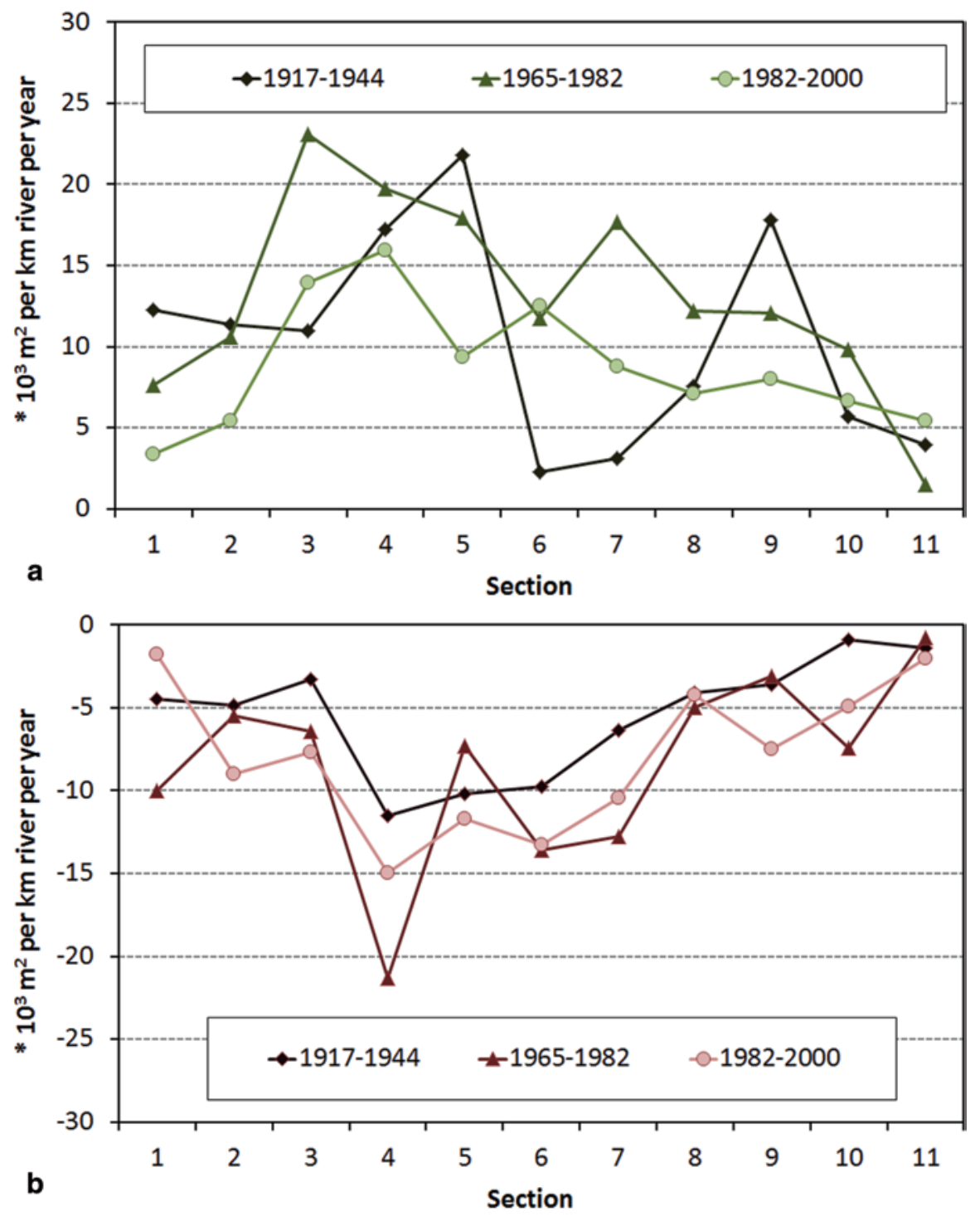

Fig. 8 a Channel bar erosion, b Deposition rates along different sections of the Lower Volga before and after dam construction. Values are averages per km per year

gradual downstream shift of the main channel in Sects. 1 and 2, and more complex changes in Sects. 3 and 4 (Fig. 9). The decrease in peak flows has also reduced flow amounts and velocities through secondary (residual) channels. This generally resulted in a more rapid silting-up of these channels, occasionally with the deposition of over $5 \mathrm{~m}$ thick sand plugs at their entrances, further obstructing flow. This has resulted in an overall increase in-channel stability, but perhaps at the expense of secondary or abandoned channels. 


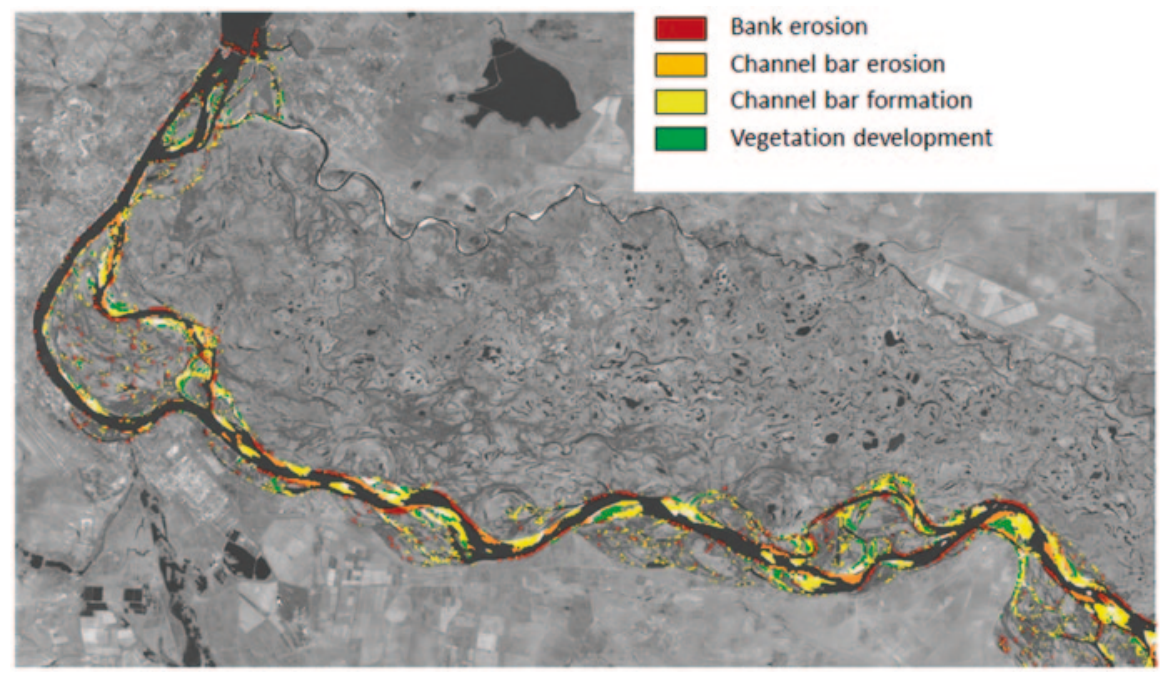

Fig. 9 Bank erosion and lateral accretion in the upper reach of the Lower Volga between 1986 and 2000 derived from Landsat TM imagery

In the subsequent $\sim 250-\mathrm{km}$ reach, comprising Sects. 3-8 (Fig. 6, 7 and 8) displays more complex adjustment. Here, major channel adjustments have occurred, characterised by the formation of large river bends, and active development of channel bars. Particularly after the river became regulated in the 1960s major meanders developed and were subsequently cut-off. Average bank erosion rates ranged from 15 to $20 \mathrm{~m}$ per year. Pre-dam floodplain accretion and erosion rates were between $\sim 7$ and $\sim 17 \times 10^{3} \mathrm{~m}^{2} \mathrm{~km}^{-1}$ per year, while bar accretion rates were highly variable between $\sim 2$ and $\sim 22 \times 10^{3} \mathrm{~m}^{2} \mathrm{~km}^{-1}$ per year. Following dam construction, bank erosion and floodplain accretion rates have decreased and have become less variable. Channel bank accretion has particularly increased in Sects. 6 and 7 (km 200-300), and bar erosion rates show an overall increase in the post-damming period.

The final $50-\mathrm{km}$ reach, before the apex of the delta, is much more stable and is primarily a single-thread meandering channel. Meander bends display little displacement with decreasing erosion and sedimentation rates towards the apex because of reduced stream power associated with a decreasing channel gradient. Lateral floodplain erosion and accretion rates have also decreased, particularly in the most recent period.

The 20-30 m high cliff of resistant bedrock and Pleistocene deposits forming the right bank of the Volga channel has been a major factor in preventing major lateral channel shifts, especially over Sects. 1, 2, 6, and 8. Erosion of the left (floodplain) bank is promoted by the saturation of the floodplain soils during the spring flood period, following the peak flow, when the Volga river stage has receded to average heights. Receding alluvial groundwater draining from high saturated banks, however, results in bank instability and subsequent collapse by mass failure. 


\subsubsection{Local Changes: Volgograd Region}

Until the 1950s the Volga Riverat the location of the present dam had a relatively straight, single thread channel, that was $2-2.5 \mathrm{~km}$ wide, and with a low gradient (300-km average downstream of Volgograd $\sim 0.03 \times 10^{-5}$ ). At $\sim 50 \mathrm{~km}$ downstream from this location the main channel is divided into two branches that merged about $20 \mathrm{~km}$ further downstream, enclosing two main islands.

The construction of the dam and sluice complex caused major morphological changes to the river channel near Volgograd (Fig. 10). In addition to the engineering construction, a new entrance of the Akhtuba channel was created because the dam was located across the natural bifurcation. Also, major dredging was required to create sufficient discharge capacity to spill the reservoir water. A navigation channel was also created to connect sluices along the eastern side of the dam to the river channel.

Dam construction resulted in about 6.5 million $\mathrm{m}^{3}$ of sediment to be removed from the active system. Until 1960 the total amount of sediment eroded at the dam area was, about 26.5 million $\mathrm{m}^{3}$. This extensive sediment production induced considerable deposition in the first tens of km downstream of the dam within several years of dam construction. After the dam had become operational, active channel erosion was progressively initiated immediately downstream of the dam. Channel deformation rates were highest during the first 10-15 years after the dam construction. Massive erosion occurred within a few tens of km downstream of the dam.

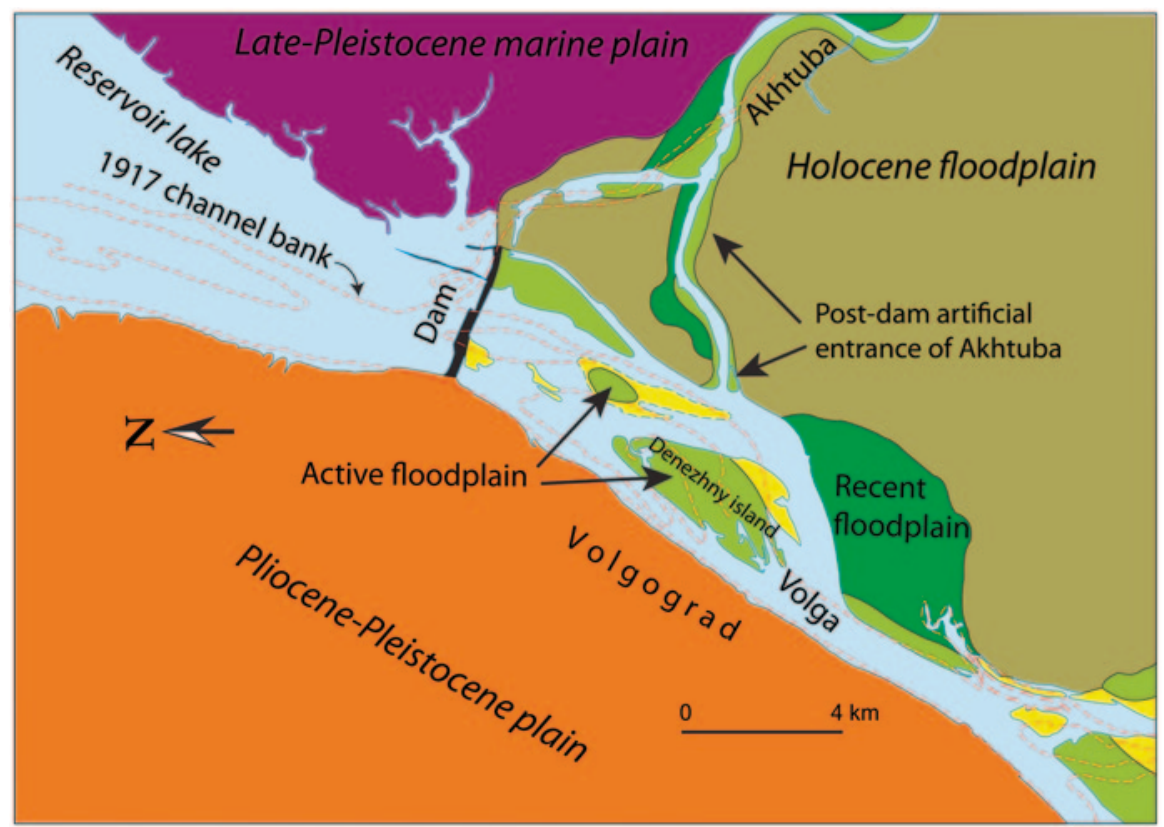

Fig. 10 Morphological overview map of the Volgograd area-situation 1980. The red line indicates the channel banks of the Volga before reservoir construction 


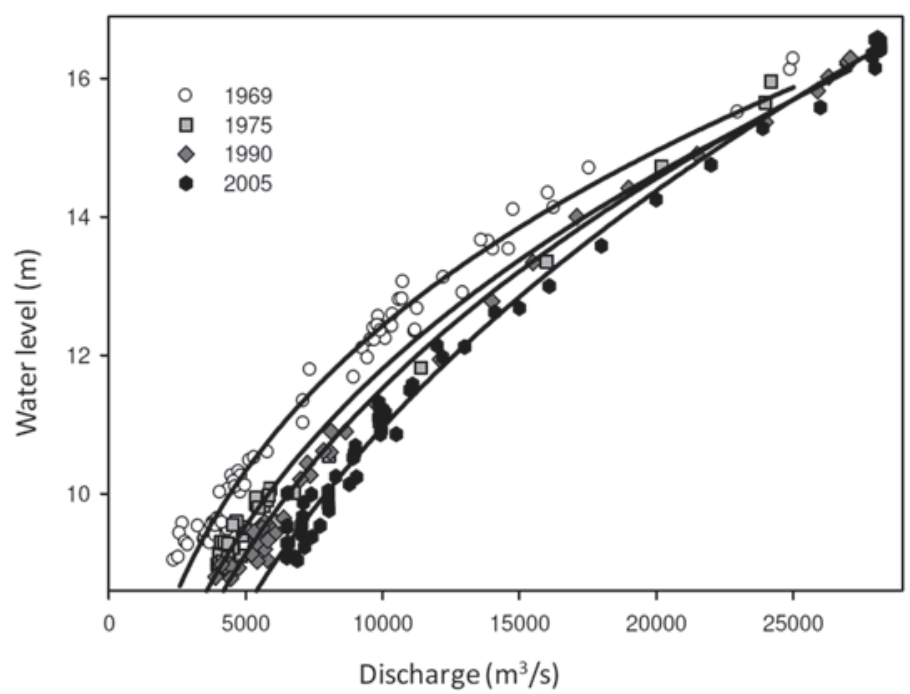

Fig. 11 Stage-discharge relationships for the Volga at Volgograd in different years after completion of the reservoir dam

Some braid bars disappeared, and the right branch around the Denezhny island $5 \mathrm{~km}$ downstream of the dam widened by $500 \mathrm{~m}$. Braid bars moved downstream at rates between 50 and $120 \mathrm{~m} \mathrm{yr}^{-1}$. The increase of low-water levels resulted in bank erosion along a large secondary channel adjacent to the large Sarpinski island complex, immediately downstream of Volgograd. The progressive channel incision reduced annual high water stages at Volgograd by about $1.3 \mathrm{~m}$ over the period $1953-1998$ for discharges equal to $10,000 \mathrm{~m}^{3} \mathrm{~s}^{-1}, 0.93 \mathrm{~m}$ for $\mathrm{Q}=20,000 \mathrm{~m}^{3} \mathrm{~s}^{-1}$, and by $0.70 \mathrm{~m}$ for $\mathrm{Q}=30,000 \mathrm{~m}^{3} \mathrm{~s}^{-1}$. This channel degradation still continues, as can be seen in stagedischarge relationships from different time periods at Volgograd (Fig. 11). Since the reservoir has become operational, total channel incision at Volgograd has been almost $2 \mathrm{~m}$. Channel bottom erosion is especially promoted by the artificially high velocities and associated with the abrupt release of the spring discharge wave from the reservoir, which results in the river stage to increase by up to $2.5 \mathrm{~m}$ per day. Water flow velocities near the channel bottom may accordingly increase to over $1 \mathrm{~m} \mathrm{~s}^{-1}$, causing rapid degradation of the $0.3-0.4 \mathrm{~mm}$ fine channel bottom sediments.

\subsubsection{Local Changes: Zakrutsky Pointbar}

Post-dam channel morphodynamics are displayed in greater detail for the Zakrutsky reach, a $10 \mathrm{~km}$ long low-sinuosity meander bend located about $90 \mathrm{~km}$ downstream from the Volgograd reservoir and dam (Figs. 1b and 6). The reach is located in the upstream reach of Sect. 3. Morphological changes were reconstructed utilizing satellite imagery, old and recent navigation maps, complemented by field surveys of the channel, point bar and floodplain. Figure 11 shows a bird's eye view of the present-day situation. 


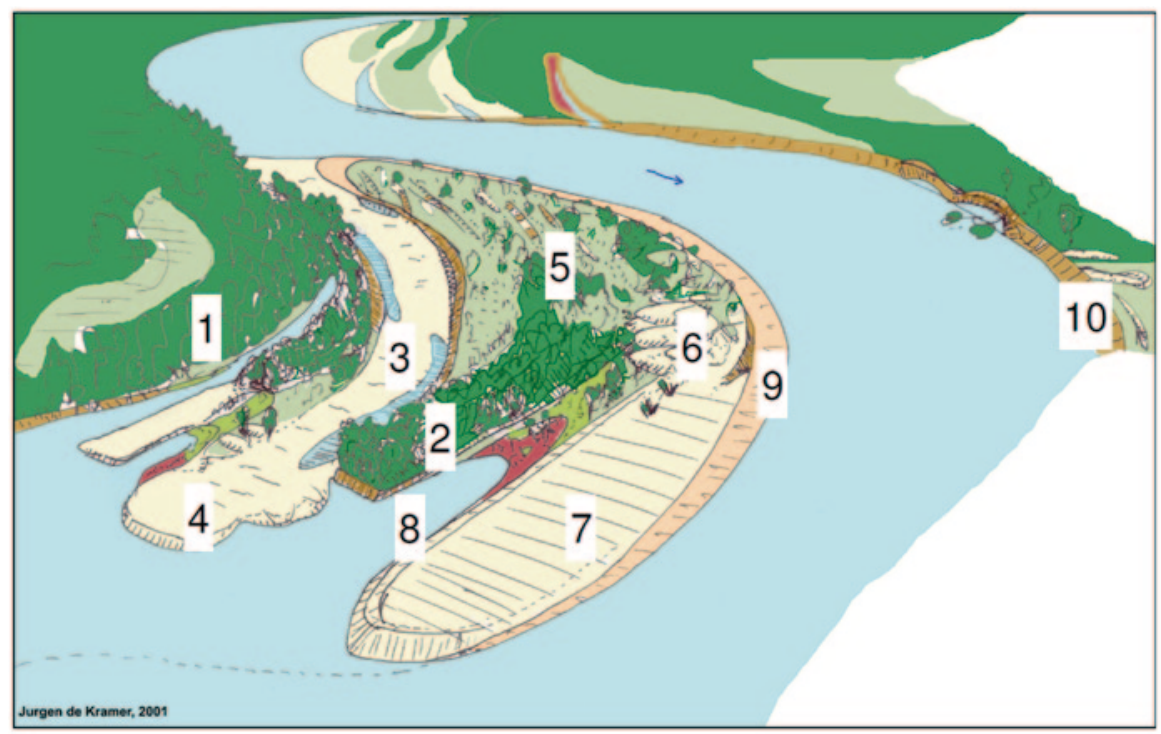

Fig. 12 Zakrutsky pointbar from a bird's eye view. Flow is towards the reader. 1 = older floodplain bar with mixed softwood-hardwood forest; $2=$ oldest part of point bar with willow forest; 3 $=$ chute channel; $4=$ chute bar; $5=$ central point bar with open vegetation; $6=$ overbank sand bars; $7=$ scroll bar; $8=$ swale channel; $9=$ inner bank, channel bars; $10=$ erosive outer bank

The channel thalweg in 1914 crossed from the southern bank in the upstream meander to the northern bank in the west, forming a riffle at the present-day location of the Zakrutsky bar, which only existed in a rudimentary form (Fig. 13). In the subsequent period until the $1960 \mathrm{~s}$, the channel bend migrated by several $\mathrm{km}$ in a downstream direction, while the Zakrutsky area developed as a sandy point bar along the southern bank. After 1962 (Fig. 14) downstream migration rates decreased. Lateral bank erosion of the northern bank occurred at a rate of $15-50 \mathrm{~m}$ per year (relative erosion rates after dividing by the channel width: $0.01-0.025 \mathrm{yr}^{-1}$ ). The point of maximum erosion of the outer bank opposite the Zakrutsky bar shifted slowly in a downstream direction, particularly after the 1980s, with annual rates of 30-140 m. Remarkably, the knick-point to the next bend did not shift downstream, as the left bank downstream the Zakrutsky bar was minimally impacted by lateral erosion. Consequently, between 1962 and 2003 the bend radius of the meander decreased from about $11.6 \mathrm{~km}$ to $6.75 \mathrm{~km}$, and the relative bend radius - obtained by dividing by channel width - decreased from 13.0 to 7.5. This might be the result of the artificial reduction of peak flows caused by the Volgograd dam (Van den Berg and Middelkoop 2007), which also decreased the adaptation length of the flow to bends. Along with the channel migration, the Zakrutsky bar at the inner bend gradually increased in size. This is revealed by examination of the planform geometry afforded by examination of 1960s Corona images. These data suggest that the bar formed as a sequence of individual bars, successively developing at the downstream point of an older bar. After 1986 a new scroll bar developed at the downstream tip 


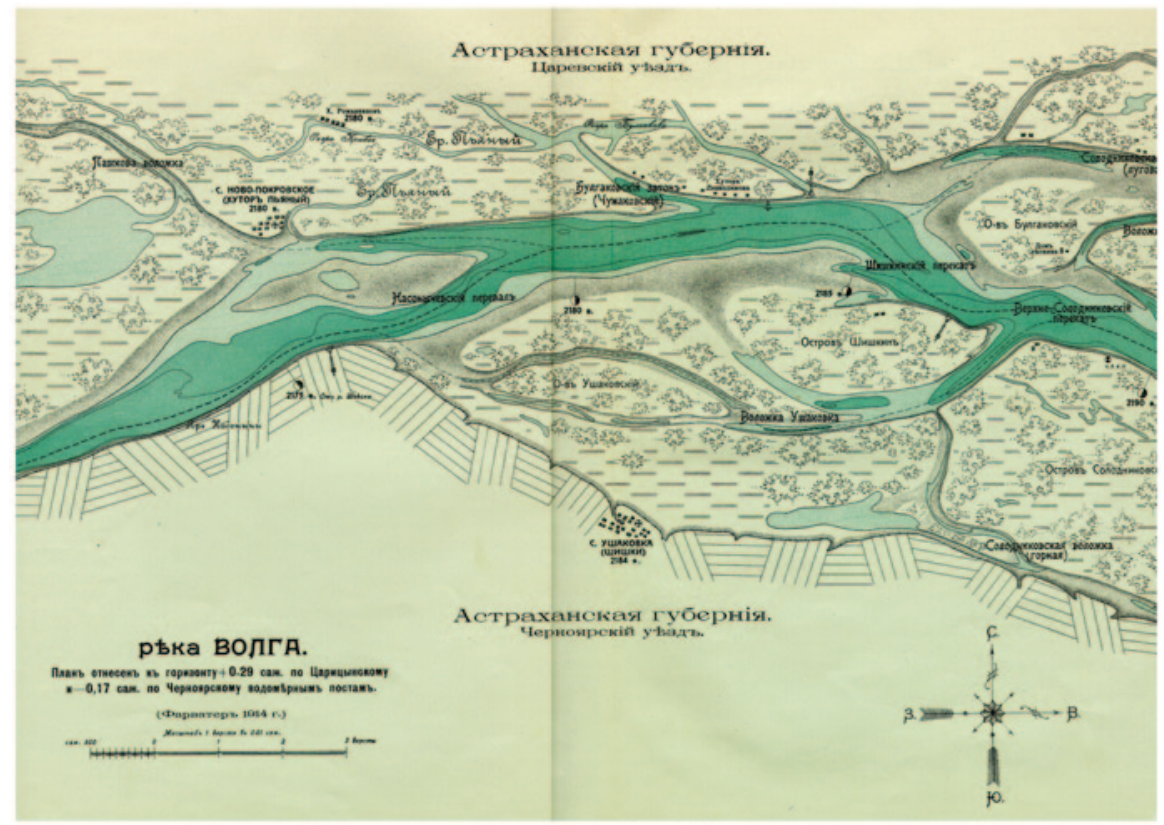

Fig. 13 Zakrutsky section according to a 1914 navigation map. The dashed line is the navigation thalweg. (Source: MPS 1917)

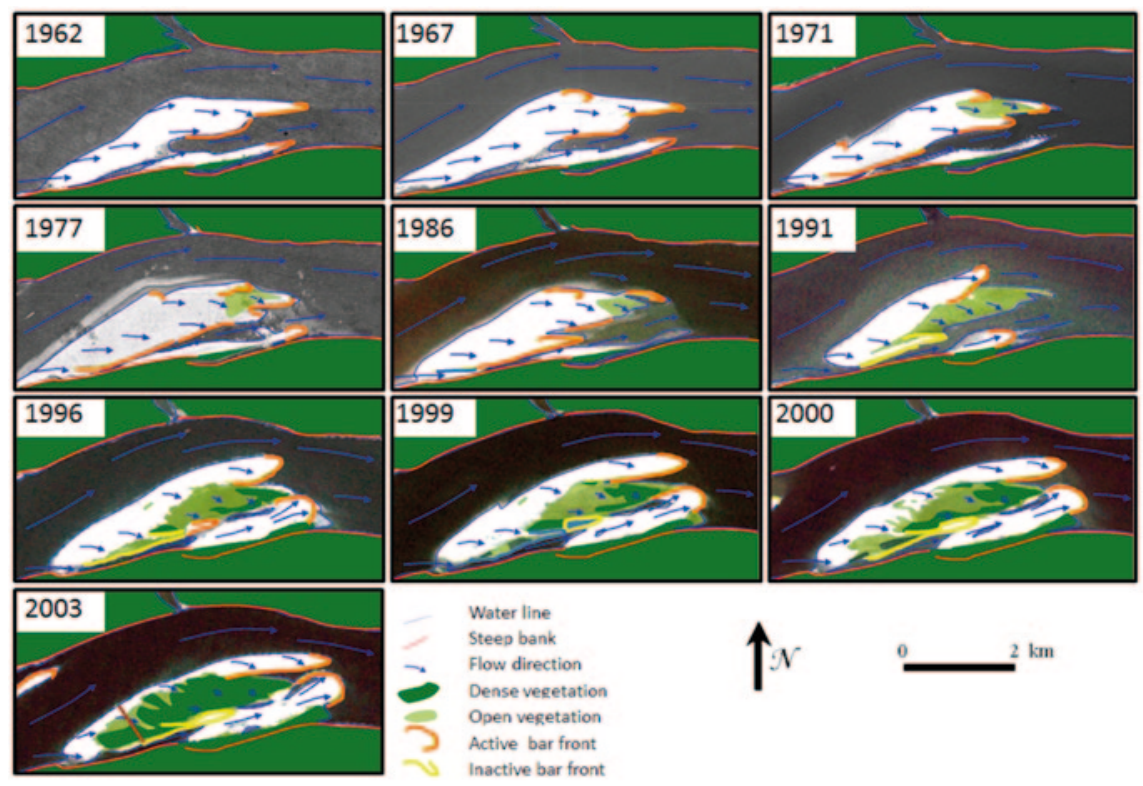

Fig. 14 Development of the Zakrutsky pointbar 1962-2003 derived from Corona and Landsat imagery 
of the existing complex, which had evolved into a large bar with top bank heights of $5 \mathrm{~m}$. The Zakrutsky pointbar complex, meanwhile, had become separated from the older floodplain by a chute channel.

Satellite images and tree ring counts indicate that in 1970 Populus colonised large portions of the northern and eastern Zakrutsky point bar, and survived vertical accretion by subsequent floods. Apparently, sedimentation rates at the proximal sides remained high, as each year young shoots from annual seedlings became buried under a new layer of sandy flood deposits. Analysis of sedimentary structures in sand pits on the northern part of the vegetated point bar revealed clear 10-20 cm thick cycles of sand layers deposited from annual floods, covered by clay drapes representing recessional flood stages. The scroll bars on the Volga point bar thus experienced rapid vertical accretion, which in large areas suppressed vegetation development for over a decade. Flow retardation within vegetated areas leads to a strong reduction in sediment transport capacity of the flow. Within the vegetated section of the Zakrutsky pointbar, annual deposition layers are considerably thinner $(5-10 \mathrm{~cm})$. After 1991, trees started to survive also in more upstream parts of the point bar, turning much of the area to a savannah type of landscape. Over the past 20 years the hydraulic roughness of the vegetation on the Zakrutsky bar has caused separation of the flow during flood stages, with increasing flow passing through the chute channel. This channel therefore has become more active and a large, up to $6 \mathrm{~m}$ thick, fan-shaped chute bar has developed at the downstream end of the bar (Fig. 12).

We contend that these processes reflect the impact of the dam construction along the Volga River, and the inherent decrease of peak flows. The reduction in peak flows was associated with a reduction in rates of lateral bank erosion, and may have also resulted in a change in planform channel geometry, specifically a reduction in meander radius rather than the progressive downstream shifting of meanders. Decreasing amounts of overbank deposition has resulted in a change in vegetation succession, from the typical bottomland floodplain vegetation of poplar and willow trees to more upland species of ash and oak which may influence flood flows. At the Zakrutsky pointbar the vegetation increasingly influenced the flow and promoted the formation of a chute, which thus effectively countered the general tendency of silting up of secondary channels as observed at other locations along the river.

\section{Conclusions and Prospects}

The impacts of the reservoir and dams along the lower Volga River had local and longer downstream impacts, over short and decadal-scale periods. Obviously, the major channel reconstruction at the dam site resulted in an abrupt change to local channel morphology. The enhanced peak flow velocities, combined with the sediment trapping of the reservoir, resulted in major changes which are continuing to unfold. In the course of decades after dam building this effect extended in a downstream direction over tens of kilometers. Importantly, the main channel and 
its banks have become the major sources of sediment transported downstream to the delta.

Morphological changes along the lower Volga comprise continued channel bank erosion, with differences between the three major river reaches remaining to exist. In the upper 100-km reach bank erosion and scroll bar deposition will continue. Within the more complex central reach, cut-off of meanders and bar accretion and erosion will remain active, while in the lowest single-thread reach meanders will continue to erode at low rates. The reduction in peak flows is reflected in two remarkably opposite responses in the development of secondary (chute) channels. Abandoned secondary channels generally tend to be in-filled with sediment, while a reduction of sediment deposition allows pioneer vegetation to colonize point bars. As a result of the inherent increasing hydraulic roughness of the vegetation, the difference between flow velocities over the vegetated pointbar ridges and those in chute channels is enhanced, leading to deepening and activation of chutes, and the formation of chute bars.

The persistent regulated discharge and lack of sediment will thus lead to a continuation of morphological changes that have been observed over the past decades. Because of the lower peak flows, vegetation is likely to colonize and develop and stabilise channel bars, and ultimately form islands. Residual channels and chute channels will further close as sand plugs develop at their entrance and are no longer eroded during peak flow. Only the deepest side channels might survive when vegetation development on the bars causes flow separation and enhances flow.

The key for water management to respond to these impacts is in the release schemes from the reservoirs, and to acknowledge the inevitable existence of reservoirs rather than consider their removal. Restoring sediment transfer from the reservoirs to the downstream reaches as e.g. occurs in the upper Rhine (Frings et al. 2014) may be considered as unfeasible because of the great size and length of the reservoirs. Moreover, polluted sediments accumulated in the lakes are suspected to become mobilized and may contaminate the lower Volga and Caspian Sea (Malik et al. 2000). This leaves the release schemes as the remaining management instrument. The degree to which more 'natural' release regimes, with higher peak flows and a different timing of the start and duration of the peak flow can be achieved obviously depends on the total amount of water available, economic demands of hydropower, irrigation and navigation and the storage capacity of the reservoirs. In this respect, future climate change becomes relevant, as this is a major control of water availability, as well as water demand for irrigation. A scenario study by Sperna Weiland (2011) evaluated for the IPCC A1B scenario shows that climate change may have considerable impact on the discharge regime of the Volga (Fig. 15). A 12GCM average projected to the year 2080 shows that summer runoff will decrease by the order of 10-20\%, winter runoff will slightly decrease, while early spring runoff will likely increase. Remarkably, the total annual amount of water decreases only by $2 \%$ according to this scenario. However, a larger difference between summer and winter runoff may pose major limitations to re-establish more natural flow regimes. Reservoirs storage capacity will be increasingly important to fulfil the increased demands for water during summer months, with less water available in this period. 


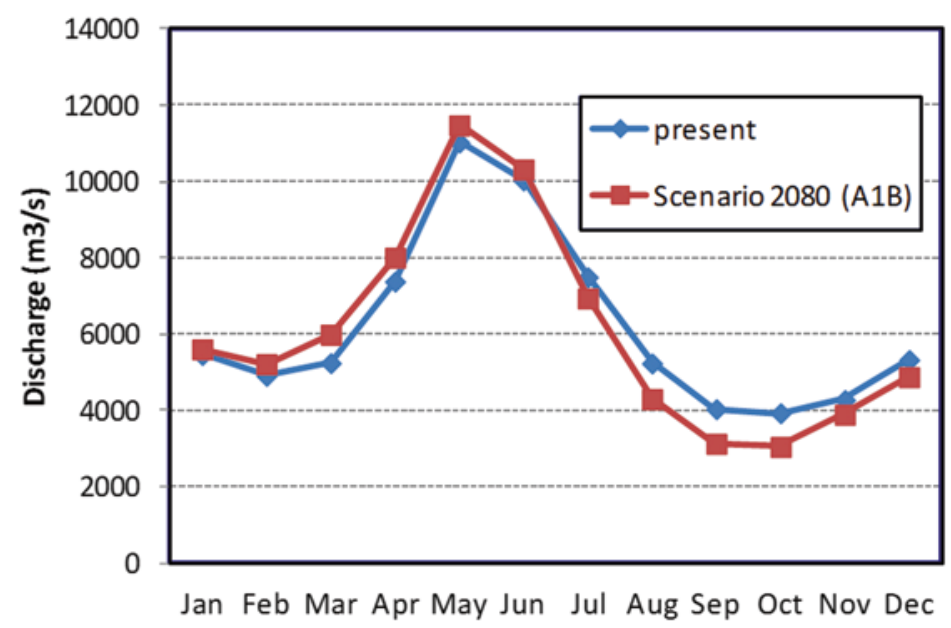

Fig. 15 Unregulated Volga runoff at Volgograd for present day and A1B scenario projected to the year 2080; multi-GCM ensemble. (Source: Sperna Weiland 2011)

This strategy will likely be at the expense of allowing larger peak flows during spring months, in spite of the larger runoff.

Acknowledgements This research was carried out with financial support of RijkswaterstaatRIZA, NWO-RFBR (grant 047.014.010). The authors thank M.M. Schoor (RIZA), M.A. Shoubin (Univ. Volgograd), M.S. Korotkov, E.A. Levashova, V.M. Moreido, M.A. Samokhin (all MSU), M. Bakker, J.H. van den Berg, A. Cormont, J. de Kramer, S. Van Rooy, M.W. Straatsma, T.J.M. van de Ven, S. van der Sluis, E. Wijma, (all Univ. Utrecht), and J.T. Dijkstra (Delft Univ.) for their contribution to the field data collection.

\section{References}

Baidin, S. S., Linberg, F. N., \& Samoilov, I. V. (1956). Hydrology of the Volga Delta (p. 331). Leningrad: Hydrometeoizdat.

Demin, A. P. (2005). The efficiency of water resources management in Volga Basin. Water Resources, 32, 594-604.

Frings, R. M., Gehres, N., Promny, M., Middelkoop, H., Schüttrumpf, H., \& Vollmer, S. (2014). Morphodynamics of a restrained river: 1. Upper Rhine Graben and Rhenish Massif. Geomorphology, 204, 573-587.

Goretsky G. I. (1966). Formation of a valley of Volga in early and middle Anthropogene. Moscow: Science.

Górski, K., Van den Bosch, L. V., Van de Wolfshaar, K. E., Middelkoop, H., Filippov, O. V., Zolotarev, D. V., Vekhov, D. A., Yakovlev, S. Y., Minin, A. E., Nagelkerke, L. A. J., Winter, H. V., De Leeuw, J. J., Buijse, A. D., \& Verreth, J. A. J. (2011). Post-damming flow regime development in a large floodplain river (Volga, Russian Federation): Implications for floodplain inundation and fisheries. River Research and Applications. doi:10.1002/rra.1499.

Ivanov, V. V., Korotaev, V. N., Rimskii-Korsakov, N. A., \& Chernov, A. V. (2006). Atlas of channel deformations in the Lower Volga. Water Resources, 33, 535-542. 
Korotaev, V. N., Ivanov V. V., \& Sidorchuk A. Yu. (2004). Alluvial relief structure and bottom sediments of the lower Volga River. Sediment Transfer through the Fluvial System (Proceedings of the Moscow Symposium, August 2004). IAHS Publ. 288. 2004, pp. 300-307.

Korotaev, V. N., Babich, D. B., \& Chalov, R. S. (2009). Atlas of channel morphodynamics of the Lower Volga. Moscow: Moscow University Press.

Malik, L. K., Koronkevich, N. I., Zaitseva, I. S., \& Barabanova, E. A. (2000). Development of dams in the Russian Federation and NIS Countries, A WCD briefing paper prepared as an input to the World Commission on Dams, Cape Town, www.dams.org.

Middelkoop, H. (Ed.). (2005). Large European river system responses to global change and human activities - The Volga and Rhine rivers. Final report of the NWO-RFBR project nr. 047.014.010. NCR-report 27-2005. Utrecht University/Moscow State University/RIZA, Utrecht/Moscow/Arnhem. ISSN 1568-234X.

MPS. (1917). Lotmanskaya Karta R. Volgi, ot Tsaritsina do Vzmorya (Navigation map of the Volga river from Tsaritsina to the coast-in Russian). Kazan, Chromo-litografiya Pravleniya Kazanskogo Okruga Putey Shoobsheniya.

Sperna Weiland, F. C. (2011). Hydrological impacts of climate change: interpretation of uncertainties introduced by global models of climate and hydrology. PhD thesis Utrecht University. Utrecht Studies in Earth Sciences 006.

Tockner, K., Uehlinger, U., Robinson, C.T. (Eds.). (2009). The rivers of Europe. London: Academic Press.

Van den Berg, J. H., \& Middelkoop, H. (2007). Scroll bar and chute bar development in meandering rivers. Two contrasting examples: The lower Volga (Russia) and the Allier (France). Proc. of the 10th Int. Symp. on River Simentation, August 1-4, 2007, Moscow, Russia, Vol. 5, pp. 282-300.

UNESCO/IRTCES. (2011). Sediment issues \& sediment management in large river basins. Interim Case Study Synthesis Report. International Sediment Initiative. Technical Documents in Hydrology. UNESCO, Beijing. 